\title{
Carbamide peroxide gel stability under different temperature conditions: is manipulated formulation an option?
}

\author{
Camila de Martini Bonesi, Letícia Storchi Ulian, Paula Balem, Valeria Weiss Angeli*
}

School of Pharmacy, Universidade de Caxias do Sul

\begin{abstract}
Nowadays the use of gel containing carbamide peroxide $(\mathrm{CP})$ prepared in Pharmacy is a normal practice in the population. However, the quality of this product is questionable concerning its stability. The aim of this study is was to synthesize and to analyze this drug alone or associated to Carbopol gel through analytical methodology compatible with the routine of the Pharmacies. The reaction between urea and hydrogen peroxide was carried out at different resting times: 24 hours (CP 24 powder) and 48 hours (CP48 powder) after the mixture. Both products were associated with Carbopol $940^{\circledR}$ gel $1.5 \%(\mathrm{G})$ generating G24 and G48 samples. The stability of powders (CP24 e CP48) and the formulations (G24 and G48) were evaluated as a function of time $\left(15,40\right.$ and 45 days) and thermal variation (refrigeration: $8{ }^{\circ} \mathrm{C} \pm 1$; thermal shock $32^{\circ} \mathrm{C} \pm 1 / 8{ }^{\circ} \mathrm{C} \pm 1$; stove: $32^{\circ} \mathrm{C} \pm 1$ ), using a standard titration method. As a result, only under refrigeration the $\mathrm{CP} 24$ and $\mathrm{CP} 48$ contents remained stable during the period of 45 days. An interesting finding was that G24 and G48 presented greater stability for at least 45-days under refrigeration and thermal shock conditions, and up to 30 days under stove conditions. The results for the G24 and G48 were slightly higher than those obtained for the control. Therefore, we were able to conclude that association with Carbopol $940^{\circledR}$ Gel $1.5 \%$ provided greater CP stability and that manipulated formulations containing $\mathrm{CP}$ may be viable for use in a period of 45 days under refrigeration conditions. The titration proved to be an effective technique for the analysis of CP with or without Carbopol $940^{\circledR}$ gel $1.5 \%$.
\end{abstract}

Uniterms: Carbamide peroxide/quantitative analysis. Carbamide peroxide/stability. Dental bleaching. Carbopol $940^{\circledR}$ gel $1.5 \%$.

\begin{abstract}
Atualmente, a utilização de gel contendo peróxido de carbamida manipulado em Farmácia é uma prática comum na população. No entanto, a qualidade deste produto é questionada, sobretudo no que se refere à estabilidade deste fármaco. O objetivo deste trabalho consiste na avaliação da viabilidade de sintetizar e analisar quantitativamente este fármaco associado ou não a um gel de Carbopol através de metodologia analítica compatível com a rotina das Farmácias. A reação entre a uréia e o peróxido de hidrogênio foi realizada em tempos diferentes de repouso após a mistura, 24 h para sintetizar o pó PC 24 e 48 h para o pó CP 48. Estes pós foram associados a um gel (G) de Carbopol $940^{\circledR} 1,5 \%$, originando as amostras G24 e G48. A estabilidade dos pós (PC 24 e PC 48) e das formulações (G 24 e G 48) foi avaliada em função do tempo $\left(15,40\right.$ e 45 dias) e da variação térmica (refrigeração: $8^{\circ} \mathrm{C} \pm 1$; choque térmico: $32{ }^{\circ} \mathrm{C} \pm 1 / 8^{\circ} \mathrm{C} \pm 1$ e estufa: $32{ }^{\circ} \mathrm{C} \pm 1$ ), através da técnica de titulometria. Os resultados indicam que unicamente sob refrigeração o CP24 e o CP 48 mantiveram-se estáveis no período de 45 dias. O G24 e o G48 apresentaram estáveis por pelo menos 45 dias nas condições de refrigeração e choque térmico e por 30 dias na condição estufa. Os resultados obtidos para o G24 e G48 foram ligeiramente superiores aos obtidos para o controle. Além disso, é possível concluir que a associação do PC com o gel de Carbopol $940^{\circledR} 1,5 \%$ promoveu um aumento na estabilidade do PC e que as preparações manipuladas contendo PC são viáveis para uso durante um período de 45 sob refrigeração. A titulometria mostrou-se uma técnica eficaz para a análise do PC associado ou não ao gel de Carbopol $940^{\circledR} 1,5 \%$.
\end{abstract}

Unitermos: Peróxido de carbamida/análise quantitativa. Peróxido de carbamida/estabilidade. Clareamento dental. Gel de Carbopol $940^{\circledR}$.

\footnotetext{
*Correspondence: V. Weiss-Angeli. Curso de Farmácia, Universidade de Caxias do Sul. Av. Francisco Getúlio Vargas, 1130. Bloco S, Cidade Universitária, 95020-272 - Caxias do Sul - RS- Brasil. E-mail: vwangeli@gmail.com; vwangeli@ucs.br
} 


\section{INTRODUCTION}

Recently, dental bleaching procedures became more popular as a result of the increasing awareness of the importance of having healthy white teeth (Gordon, Chiritensen, 2005). Dental darkening may be caused by extrinsic factors (e.g. smoking, food or beverages with pigments), or intrinsic factors either congenital (e.g. imperfect dentinogenesis) or acquired (e.g. use of tetracyclines, fluorine or trauma) (Goldstein, 2000). Nowadays, two bleaching techniques are commonly used. The home-bleaching technique implies on using a low concentration of CP gel dental strips for an average period of 2 to 3 weeks, and is becoming increasingly popular. On the other hand, the office technique, although older, was not frequently used until recently due to the difficulties associated with the hydrogen peroxide solution application and the need for absolute isolation (Papathanasiou et al., 2002; Wetter et al., 2009).

The carbamide peroxide (CP), also known as urea peroxide, hydrogen peroxide-urea or urea-peridrol, was initially used as an anti-inflammatory in the great wars to treat periodontal diseases (Gonçalvez et al., 2001; Gratão et al., 2003). Starting in 1960, it has been used in the form of antiseptic solutions $(10 \% \mathrm{CP})$ for the treatment of gingivitis in children and adults by the orthodontist William Klusmier, in which the tooth whitening occurred as a side effect of the anti-septic property. After this event, in 1989, Haywood and Heymann published the first article about tooth whitening with $\mathrm{CP}$ at concentrations ranging from 10 $\%$ to $20 \%$ (Gonçalvez et al., 2001; Compoy et al., 2001; Goldstein, 2000).

The action mechanism of bleaching consists in the oxidation reaction of the CP bleaching agent, which in contact with the saliva or gingival tissue is broken down into hydrogen peroxide and urea. The urea produces ammonia and carbon dioxide, contributing to the maintenance of an alkaline $\mathrm{pH}$, which potentiates the action of the bleaching agent (Sun, 2000). The hydrogen peroxide diffuses through the organic matrix of enamel and dentin, releasing free radicals that break $\mathrm{O}_{2}$ carbon rings of high molecular weight from darker pigmentation, converting them into clearer smaller molecules (Compoy et al., 2001; Rodrigues et al., 2005; Goldberg et al., 2009). Nevertheless, for bleaching gel to act on enamel and dentin, it is necessary for it to diffuse through the dental tissues. It is known that the greater the surface tension of a liquid, the lower its ability to diffuse through a surface or to wet it. After the bleaching treatment changes have been observed in surface texture (Potocnik et al., 2000) mineral content (Attin et al., 2005), chemical composition (Justino, Demarco,
2004) and loss by tooth brushing abrasion (Wiegand, Attin, 2004). The addition of surfactants to hydrogen-peroxidebased bleaching gel resulted in a significantly more extensive bleaching (Canepelle, Torres, 2011).

The other application for $\mathrm{CP}$ is in the treatment for plaque, gingival health and caries, so antibacterial activity has been studied (Nunes et al., 2011). Plaque accumulation and resulting caries or periodontal disease is a frequent problem in patients with special-care needs. Lazarchik and Haywoode reviewed in 2010 the antibacterial properties of $\mathrm{CP}$ and the effects of $\mathrm{CP}$ on saliva, plaque, caries and gingival health. They addressed the challenges involved in the research needed regarding the use of tray-applied $\mathrm{CP}$ materials in special-care patients. The results showed that $\mathrm{CP}$ at $10 \%$ may be a great promise for improving the oral health of many special-care patients, including elderly patients, patients with cancer and patients with dry mouth.

The technique described by Haywood and Heymann was improved when the $\mathrm{CP}$ was associated with the $\mathrm{Carbopol}^{\circledR}$ gel at $1.5 \%$. Carbopol is a thickening agent, of thixotropic nature, used in the process to stabilize the dissociation of the bleaching agent, releasing oxygen more slowly, increasing the time of action of the product formulation and adhesion to tooth structure (Compoy et al., 2001; Apple, Reus, 2003).

The bleaching agents, however, are chemically very unstable (Baratieri et al., 2004). The commitment of their stability is related to factors such as temperature, light, moisture, $\mathrm{pH}$, impurities and others (Ansel et al., 2000). Thus, stability tests to predict monitoring and to determine the validity and the ideal storage conditions are needed.

The products used for dental bleaching could be prepared by the industry and by the pharmacist. The manipulated products have questionable quality, because of the low stability of CP. Therefore, the studies about applicable analytical methodologies in pharmacy practice contribute to the quality certification of the products.

The aim of this work was to analyze the synthesis of $\mathrm{CP}$, through the reaction of hydrogen peroxide and urea for 24 and 48 hours and subsequent percentage evaluation of $\mathrm{CP}$ in the synthesized product. Moreover, the work was to study the incorporation of active Carbopol $940^{\circledR}$ gel at $1.5 \%$ and stability evaluation of both the $\mathrm{CP}$ and the $\mathrm{CP}$ gel as a function of time and temperature variation, with the aim to establish a protocol for monitoring its adaptive stability reality of pharmacies.

\section{METODOLOGY}

The CP was synthesized using urea (All Chemistry) and hydrogen peroxide $130 \mathrm{~V}$ (All Chemistry) in equal 
proportions. Urea was crushed in porcelain mortar and then hydrogen peroxide $130 \mathrm{~V}$ was added. The mixture was divided into two portions, covered with plastic wrap and kept at rest for $24 \mathrm{~h}$ and $48 \mathrm{~h}$ respectively, in the dark, resulting in the samples CP24 and CP48. After this period, both portions were vacuum filtered and the solids were stored in desiccators for 24 hours (USP 27 2004; Zanardi et al., 2007).

For the Carbopol $940^{\circledR}$ gel at $1.5 \%$ containing CP preparation, $16 \%$ of CP2 4 was incorporated, taking into account its level, in $60 \%$ Carbopol 940 gel at $1.5 \%$. It was also added $0.3 \%$ of sodium fluoride as a desensitizing agent. The same procedure was repeated for CP48, resulting in samples G24 and G48, respectively. The controls used for this experiment consisted of $\mathrm{CP}$ in the dust from Merck (Dust Control) and the gel of CP 16\% of Whiteness Perfect $^{\circledR}$ (FGM Control).

Samples CP24, CP48, G24 and G48 and controls were stored in bottles, milky plastic and syringes respectively sealed, and then exposed to three different temperature conditions for the experiment: a) Thermal Shock: $32{ }^{\circ} \mathrm{C} \pm 1 / 8^{\circ} \mathrm{C} \pm 1{ }^{\circ} \mathrm{C}$; b) Stove: $32{ }^{\circ} \mathrm{C} \pm 1{ }^{\circ} \mathrm{C}$ and c) Refrigeration: $8 \pm 1{ }^{\circ} \mathrm{C}$.

The CP determination in the samples and controls, stored under different conditions, was done by quantitative iodometric (titrimetric), taking as a basis the methodology described in the United States Pharmacopeia (USP 27, 2004). It was done in triplicate at predetermined dates, divided into 4 different times totaling 45 days. Then, $100.00 \mathrm{mg}$ of CP were weighed, and this amount was transferred to an Erlenmeyer flask of $500 \mathrm{~mL}$. For the gel, $625.00 \mathrm{mg}$ were weighed on a CP $500 \mathrm{~mL}$ flask, which corresponds to $100.00 \mathrm{mg}$ of CP. Later, distilled water, acetic acid PA, potassium iodide and sodium molybdate $10 \%$ (aqueous solution) were added. The solution was homogenized and then maintained under light for $10 \mathrm{~min}$. The liberated iodine was titrated with aqueous $0.05 \mathrm{M}$ sodium thiosulfate TS. Near the turning point, $3.00 \mathrm{~mL}$ of $2 \%$ starch indicator were added, changing the color from dark blue to colorless.

Considering that each $\mathrm{mL}$ of $0.05 \mathrm{M}$ sodium thiosulfate TS is equivalent to $4.704 \mathrm{mg}$ of $\mathrm{CP}$, the concentration percentage was calculated for the samples and controls. The average return and standard deviation of the results were calculated. The effects of different storage conditions $\left(8{ }^{\circ} \mathrm{C} \pm 1 ; 32{ }^{\circ} \mathrm{C} / 8^{\circ} \mathrm{C} \pm 1 ; 32{ }^{\circ} \mathrm{C} \pm 1\right)$, time $(15,30$ and 45 days), formulation (G24, G48 and Control) and their interactions were assessed using factorial design analysis for three factors by ANOVA followed by Tukey post-test $(\alpha=0.05)$. It was used SPSS (Statistical Package for the Social Sciences) 17.0 for Windows.

\section{RESULTS AND DISCUSSION}

Table I shows the results of the CP content in the samples and controls, obtained by titrimetric assay at different temperature conditions in which they were exposed for a period of 45 days.

The concentration of CP in the samples CP24, CP48 and control at time zero (after preparation), showed an average concentration of $98.31 \%, 99.01 \%$ and $97.85 \%$, respectively (Table I); values were considered within pharmacopoeial limits of $96 \%$ to 102 (USP 27, 2004), with no significant statistically difference between them (tukey test, $\mathrm{p}<0.05)$. Threshold values of concentration of CP gel incorporated into Carbopol $940^{\circledR}$ were not found in the literature.

TABLE I - Evaluation of CP content in the powder and gel pharmaceutical forms under different temperature conditions

\begin{tabular}{|c|c|c|c|c|c|c|c|c|c|c|}
\hline \multirow{3}{*}{ Samples } & \multicolumn{10}{|c|}{ CP Content $(\%) \pm$ S.D } \\
\hline & \multirow{2}{*}{$\begin{array}{c}\text { After } \\
\text { preparation (AP) } \\
\text { (Zero Time) }\end{array}$} & \multicolumn{3}{|c|}{$8^{\circ} \mathrm{C} \pm 1$} & \multicolumn{3}{|c|}{$32^{\circ} \mathrm{C} \pm \mathbf{1} / \mathbf{8}^{\circ} \mathrm{C} \pm 1$} & \multicolumn{3}{|c|}{$32{ }^{\circ} \mathrm{C} \pm 1$} \\
\hline & & \multicolumn{3}{|c|}{ Days } & \multicolumn{3}{|c|}{ Days } & \multicolumn{3}{|c|}{ Days } \\
\hline CP24 & $98.31 \pm 0.44$ & $98.27 \pm 0.19$ & $96.67 \pm 0.36$ & $96.04 \pm 0.50$ & $94.67 \pm 0.14$ & $68.42 \pm 0.40$ & $35.35 \pm 0.85$ & $1.41 \pm 0.02$ & - & - \\
\hline CP48 & $99.01 \pm 0.88$ & $98.24 \pm 0.84$ & $96.87 \pm 0.34$ & $95.22 \pm 0.32$ & $93.70 \pm 0.44$ & $69.06 \pm 0.09$ & $35.37 \pm 0.40$ & $1.40 \pm 0.04$ & - & - \\
\hline G24 & $100.39 \pm 0.64$ & $101.40 \pm 0.25$ & $100.90 \pm 0.31$ & $100.25 \pm 0.50$ & $99.73 \pm 0.50$ & $98.08 \pm 0.63$ & $96.21 \pm 0.29$ & $99.79 \pm 0.04$ & $97.19 \pm 0.27$ & $94.00 \pm 0.32$ \\
\hline G48 & $100.16 \pm 0.58$ & $101.40 \pm 0.31$ & $100.25 \pm 0.00$ & $99.73 \pm 0.47$ & $101.00 \pm 0.77$ & $99.48 \pm 0.29$ & $97.02 \pm 1.81$ & $98.92 \pm 1.16$ & $96.07 \pm 0.27$ & $89.89 \pm 0.28$ \\
\hline $\begin{array}{l}\text { FGM Control } \\
\text { (gel) }\end{array}$ & $99.75 \pm 0.55$ & $99.26 \pm 0.39$ & $98.76 \pm 1.04$ & $98.57 \pm 0.42$ & $99.59 \pm 0.27$ & $97.70 \pm 0.08$ & $95.37 \pm 1.12$ & $97.22 \pm 0.35$ & $91.35 \pm 1.01$ & $89.29 \pm 0.75$ \\
\hline
\end{tabular}

CP: carbamide peroxide; CP24: carbamide peroxide powder after $24 \mathrm{~h}$; CP48: carbamide peroxide powder after $48 \mathrm{~h}$; G24: carbamide peroxide gel containing CP24; G48: carbamide peroxide gel containing CP48. 
The results demonstrated in Table I showed that the samples CP24 and CP48 in the refrigeration condition $\left(8^{\circ} \mathrm{C} \pm 1\right)$ had no statistical difference compared to their control at time zero, 15 and 30 days (tukey test, $\mathrm{p}<0.05$ ). However, in 45 days the CP48 and control showed a significant CP decrease of $3.79 \%$ and $2.61 \%$ respectively (Table I): This decrease is within the acceptable limit variation of $5 \%$ in stability studies recommended in $\mathrm{RE}$ $\mathrm{n}^{\circ} 1.5$ (Brazil, 2005).

Regarding the heat shock condition $\left(32^{\circ} \mathrm{C} \pm 1 /\right.$ $8^{\circ} \mathrm{C} \pm 1$ ), the $\mathrm{CP} 24$ control remained stable during the first 15 days, differing from CP48. After 45 days of exposure, the CP24 and CP48 samples showed a decrease in the CP levels of $64 \%$. Only the control remained stable with a reduction of only $5.2 \%$.

In stove conditions $\left(32{ }^{\circ} \mathrm{C} \pm 1\right), \mathrm{CP} 24$ and $\mathrm{CP} 48$ samples showed a substantial decrease in the $\mathrm{CP}$ level that started at 15 days of exposure, resetting the $\mathrm{CP}$ content over time. This may be related to the decomposition of $\mathrm{CP}$ in ammonia (urea), oxygen and water (hydrogen peroxide) at temperatures above $30^{\circ} \mathrm{C}$ (Gratae et al., 2003; Basting, 2006; Leonard et al., 1994). The dust control in this condition showed a slight CP decrease after 30 days, but remained constant at the end of 45 days. This ambiguity of behavior for the $\mathrm{CP} 24$ and $\mathrm{CP} 48$ in comparison to controls, tested under different conditions can be attributed to different experimental conditions in the methods of obtaining these substances. The resolution $\mathrm{RE}^{\circ} 01 / 05$ on pharmaceutical active establishes that stability depends on temperature, humidity, light and other factors relating to the product itself (physical and chemical properties). In addition, one must consider other aspects that can interfere with stability of assets such as: presence or absence of excipients, the dosage form type, manufacturing process and material packaging (Brazil, 2005).

The samples containing the $\mathrm{CP}$ associated with the Carbopol $940^{\circledR}$ gel $1.5 \%$ (G24 and G48), when subjected to cooling showed statistical difference in $\mathrm{CP}$ content, when compared to control.

With regard to exposure of the same samples to heat shock $\left(32{ }^{\circ} \mathrm{C} \pm 1 / 8^{\circ} \mathrm{C} \pm 1\right)$, it was found that all samples were stable during the first 15 days. After 30 days, the G24 had a decreased percentage of $\mathrm{CP}$ which was not observed for G48 and control. In 45 days the G24 was the formulation that showed the most reduced levels of CP; however, this reduction was not significant, indicating stability of these formulations at the end of 45 days. The control gel at the end of 45 days showed a content change, demonstrating the instability of this vehicle in the tested condition. The G48 formulation was stable for 45 days on the studied condition temperature.
The display results under stove $\left(32^{\circ} \mathrm{C} \pm 1\right)$ showed that the increase in temperature led to a decreased $\mathrm{CP}$ percentage after 30 days for all samples; however, this reduction was more significant for the control FGM (8.40\%). After 45 days, there was a reduction of $6.39 \%$ for $\mathrm{G} 24$, $10.27 \%$ for G48 and $10.46 \%$ for the control. According to Aulton (2005) such behavior is expected due to the drastic conditions of storage. Increasing the temperature at $10{ }^{\circ} \mathrm{C}$ produces a 2-5 fold increase in the drugs degradation.

Figure 1 shows the statistical analysis of the gel containing $\mathrm{CP}$ in the different experimental conditions (time, storage conditions and formulation). Factor analysis applied significant difference $\mathrm{p}$ (probability values) $<0.01$ for the main factors by the ANOVA for three factors. The comparison of means by Tukey test $(\alpha=0.05)$ has shown that the storage of $\mathrm{CP}$ gel at low temperatures $\left(8 \pm 1{ }^{\circ} \mathrm{C}\right)$ is more appropriate, and therefore recommended it as the condition for storage of the Carpobol $940^{\circledR}$ gel $1.5 \%$ containing CP. It is possible to verify that the temperature exerts a strong influence on the CP decay associated to Carpobol $940^{\circledR}$ gel $1.5 \%$. Higher temperatures cause oscillation of the decay of this drug. This influence can be observed mainly for the CP powder. It is possible to show that the drug contents decrease as a function of time, since the observed differences are significant fortnightly. This observation is particularly useful for estimating an expiration date for the compounded product, through the results one can estimate a validity of at least 45 days for the product stored in the refrigerator.

A comparison of results between the G24, G48 and FGM control in different conditions, demonstrated that the G24 e G48 showed higher CP content than the control. This result is positive in demonstrating that manipulated formulations were similar to industrialized formulations, setting the feasibility and safety in the preparation of this formulation in masterful scale. Considering the results for the G24 and G48, one can realize that the time of synthesis of CP is not directly influenced by the quality of the final product, since there was no significant difference in $\mathrm{CP}$ content for these samples.

Considering these results, it was possible to show a greater reduction in CP level in powder than in Carbopol $940^{\circledR}$ gel $1.5 \%$. Studies that evaluate the stability of the drug in isolated solid state and in the presence of excipients are important during the stage of pre-formulation of a product. Studies of stability of the formulation as a whole prioritize the evaluation of the drugs behavior over time considering the drug, the mixture of excipients or used vehicles, as well as the interaction between them, in different conditions (Brazil, 2005; Mamede et al., 2006). The present results have highlighted the importance that the 




FIGURE 1 - Results of percentage of the major factors evaluated. Values represent the mean of each level and the associated error bars.

dosage form provides to the system as a whole, protecting the active ingredient from degradation caused by the agents tested (Baratieri et. al., 2004).

\section{CONCLUSION}

In relation to the $\mathrm{CP}$ synthesis, one can say that it was feasible to carry it through because it is an easy and affordable methodology. Based on the temperature conditions described and in accordance with the valuation method (titration), the results showed that the best form of storage for the $\mathrm{CP}$ dust is under refrigeration $\left(8^{\circ} \mathrm{C} \pm\right.$ 1 ), since the results indicate no significant decrease in $\mathrm{CP}$ levels when exposed to this condition. The association of $\mathrm{CP}$ in the Carbopol $940^{\circledR}$ gel $1.5 \%$ provided greater CP stability, showing the importance of the dosage form in the protection of the active substance, having no significant difference between samples prepared with synthesized CP at different times.

This paper presented relevance with regard to its applicability in monitoring the $\mathrm{CP}$ content in powder and Carbopol 940 gel $1.5 \%$ to be easily adapted into a pharmacy routine. Thus, it can be ensured that the manipulated formulations in the Carbopol 940 gel at $1.5 \%$ containing $\mathrm{CP}$ are viable for use in a period of 45 days when stored under refrigeration.

\section{REFERENCES}

ANSEL, H.C.; POPOVICH, N.G.; ALLEN JR., L.V. Farmacotécnica: formas farmacêuticas e sistemas de liberação de fármacos. 6.ed. São Paulo: Premier, 2000. p.135-140.
APPEL, G.; REUS, M. Formulações aplicadas à odontologia. São Paulo: RCN Editora, 2003. p.142-143.

ATTIN, T.; VOLLMER, D.; WIEGAND; A.; ATTIN, R.; BETKE, H. Subsurface microhardness of enamel and dentin after different external bleaching procedures. Am. J. Dent, v.18, n.1, p.8-12, 2005.

BARATIERI, L.N.; ANDRADA, M.A.C.; MONTEIRO JR., S.; VIEIRA, L.C.C.P. Clareamento dental. São Paulo: Santos Editora, 2004. p.129.

BASTING, R.T. Peróxido de carbamida: efeitos na micromorfologia e rugosidade das estruturas dentais. Arq. Odont., v.41, n.1, p.21-27, 2006.

BRASIL. Agência Nacional de Vigilância Sanitária. Resolução RE n. 01, de 29 de Julho de 2005. Autoriza ad referendum, a publicação do Guia para a Realização de Estudos de Estabilidade Diário Oficial da União. Brasília, DF, 01 de ago.2005. Available at: $<$ http://www.anvisa.gov.br/ e-legis/>. Accessed on: 18 dec. 2008.

CAMPOY, C.D.; ALVES, R.H.S. Clareamento caseiro: revisão de literatura. São José dos Campos, 2001. 34 p. [Monografia de Graduação. Faculdade de Ciências da Saúde, Universidade do Vale do Paraíba. São José dos Campos].

CANEPPELE, T.M.F.; TORRES, C.R.G. Influence of surfactants on the effectiveness of bleaching gels. Clin. Oral Invest., v.15, n.1, p.57-64, 2011.

GOLDBERG, M.; GROOTVELD, M.; LYNCH, E. Undesirable and adverse effects of tooth-whitening products: a review. Clin. Oral Investig., v.14, n.1, p.1-10. 2009.

GOLDSTEIN, R.E. A estética em odontologia. 2.ed. São Paulo: Livraria Santos, 2004. 884 p.

GONÇALVEZ, F.C.; MONTE ALTO, L.A.; RAMOS, M.E.B. Alteração cromática e morfológica do esmalte dental após tratamento com peróxido de carbamida 10\%. J. Bras. Clin. Odontol. Integ., v.5, n.29, p.413-417, 2001.

GORDON, J.; CHIRISTENSEN, D.D.S. Are snow-white teeth really so desirable? J. Am. Dental Assoc., v.136, n.7, p.933935, 2005.

GRATÃO, I.C.; CRUZ, F.S.; SHIMOMURA, M. Clareamento dental caseiro: Relato de um caso clínico. Odontol. Estetic., v.7, n.11, p.7-9, 2003. 
JUSTINO, L.M.; TAMES, D.R.; DEMARCO, F.F. In situ and in vitro effects of bleaching with carbamide on human enamel. Oper. Dent., v.29, n.2, p.219-25, 2004.

LAZARCHIK, D.A.; HAYWOOD, V.B. Use of tray-applied 10 percent carbamide peroxide gels for improving oral health in patients with special-care needs. J. Am. Dent. Assoc., v.141, n.6, p.639-646, 2010.

LEONARD JR., R.H; AUSTIN, S.M.; HAYWOOD, V.B.; BENTLEY, C.D. Change of $\mathrm{pH}$ of plaque and $10 \%$ carbamide peroxide solution during nightguard vital breaching treatment. Quintessence Int., v.25, n.12, p.819823, 1994.

MAMEDE, L.C.; CAETANO, B.L.; ROCHA, L.A.; FERREIRA, E.M.; CESTARI, A.; KFURI, C.R.; CIUFFI, K.J.; CALEFI, P.S.; MELLO, C.; CUNHA, W.R.; NASSAR, E.J. Comportamento térmico de alguns fármacos e medicamentos. Rev. Ciênc. Farm. Básica Apl., v.27, n.2, p.151-155, 2006.

NUNES, V.H.S.; ANDRADE, A.O.; VILAR, R.V.; MOREIRA, R.F.; HIRATA, R.; MONNERAT, A.F.; FRAGA. R.C. A influência do peróxido de carbamida sobre a formação de colônias de estreptococos do grupo mutans. Rev. Bras. Odontol., v.68, n.1, p.124-127, 2011.

PAPATHANASIOU, A.; KASTALI, S.; PERRY, R.D.; KUGEL, G. Clinical evaluation of a $35 \%$ hydrogen peroxide in-office whitening system. Compend. Contin. Educ. Dent., v.23, n.4, p.335-338, 340, 343-344 passim; quiz 348, 2002.
POTOCNIK, I.; KOSEC, L.; GASPERSIC, D. Effect of 10\% carbamide peroxide bleaching gel on enamel microhardness, microstructure, and mineral content. J. Endodont, v.26, n.4, p.203-206, 2000.

RODRIGUES, J.A.; OLIVEIRA, G.P.F.; AMARAL, C.M. Avaliação in vitro da efetividade de diferentes sistemas clareadores caseiros. Arq. Odontol., v.41, n.1, p.101-105, 2005.

SUN, G. The role of lasers in cosmetic dentistry. Dent. Clin. $N$. Am., v.44, n.4, p.831-850, 2000.

THE UNITED STATES PHARMACOPOEIA. The official compendio of standards. Rockville: United States Pharmacopeial Convention, 2004. p.325.

WETTER, N.U.; BRANCO, E.P.; DEANA, A.M.; PELINO, J.E. Color differences of canines and incisors in comparative long term clinical trial of three bleaching systems. Laser Med. Sci., v.24, n.6, p.941-947, 2009.

WIEGAND, A.; OTTO, Y.A.; ATTIN, T. In vitro evaluation of toothbrushing abrasion of differently bleached bovine enamel. Am. J. Dent., v.17, n.6, p.412-416, 2004.

ZANARDO, M.V.; OHLWEILER, J.Z.; ZANLORENZI, R.S.C.S.; MAY, C.; CONCI, R.;FARAGO, P.V. Gel de peróxido de carbamida: critérios à manipulação. Encarte Técnico Anfarmag, v.13, n.66, p.2-11, 2007.

Received for publication on $20^{\text {th }}$ February 2011 Accepted for publication on $23^{\text {rd }}$ September 2011 